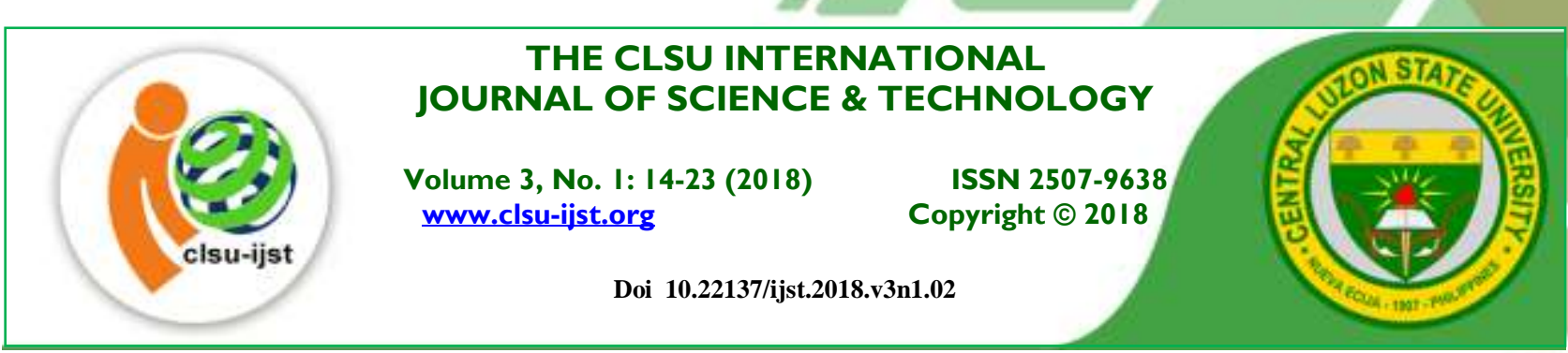

\title{
Evaluation of Different Forage Type Varieties of Pigeon Pea (Cajanus cajan) in Central Luzon
}

\author{
Leny Lyn G. Manalili, ${ }^{1}$ Emilio M. Cruz ${ }^{1}$, Edgar A. Orden ${ }^{1}$, Charlito R. Juico ${ }^{2}$ \\ and Neal A. Del Rosario ${ }^{1}$ \\ ${ }^{1}$ Small Ruminant Center, Central Luzon State University, Science City of Munoz, Nueva Ecija, ${ }^{2}$ Research Office, \\ Research Extension and Training, Central Luzon State University, Science City of Munoz, Nueva Ecija \\ *Email for correspondence: lenylyn_manalili@yaboo.com
}

\begin{abstract}
Pigeon pea (Cajanus cajan) is a drought-tolerant dual-purpose crop primarily grown as grain crop for human consumption. The ability of pigeon pea to produce economic yields under moisturedeficient soils makes it as an ideal crop to integrate in the crop-livestock farming for production of high-quality fodder.

Four pigeon pea forage-type variety of the International Crop Research Institute for the SemiArid Tropics (ICRISAT), namely: ICPL 87119, ICPL 13092, ICP 7035, and ICPL 20092, were planted to identify the best variety that is suitable under Central Luzon agro-climatic conditions. A total of 240 plants per variety were planted with $0.5 \mathrm{~m} \times 0.75 \mathrm{~m}$ planting distance. The experiment plots were laidout using Randomized Complete Block Design with three replications at the Central Luzon State University. The varieties were evaluated by measuring the growth performance, herbage yield, dry matter yield, and disease tolerance.

Results showed significant variations in the survival rate of the different varieties. All varieties exhibited less than $85 \%$ survival rate. Among the varieties, ICP 7035 produced the highest herbage yield per hectare of 8.9 tons which was $24.71 \%, 58.42 \%$, and $68.53 \%$ higher compared to ICPL 87119 , ICPL 20092, and ICPL 13092, respectively. Likewise, ICP 7035 showed the highest performance in all agronomic parameters measured except leaf to stem ratio. High leaf to stem ratio of 3.18:1 was observed from ICPL 20092. However, ICPL 20092 was severely infested by mites (98\%), while the rest were found to be resistant to mite infestation.
\end{abstract}

Key words : agronomic parameter, forage, ICRIS AT, Pigeon pea 


\section{INTRODUCTION}

Pigeon pea (Cajanus cajan) is a short-lived (3-5 years) perennial forage shrub. It has strong deep tap root system and large food reserve which help the plant to survive under unfavorable conditions such as drought (Saxena et al., 2010). It can adapt to a wide range of soil types from gravel-like soil to heavy clays, provided there is no standing water on the soil surface. It can tolerate moderate salinity and alkalinity but not severely acid soils. As a crop, pigeon pea is capable of growing in dry season exceeding six months or rainfall less than $300 \mathrm{~mm}$, but perform best to areas with $600-1,000 \mathrm{~mm}$ average annual rainfall (Cook, et al., 2005).

Pigeon pea is a popular source of vegetable protein in the human diet and as animal feed (Sharma et al., 2011). It produces high quality fodder and can be integrated to crop livestock farming system as feed supplement (Rao et al., 2003). According to Van Soest (1994), feedstuff are often deficient in nitrogen that allow efficient feed digestion. In the study conducted by Saxena (2006), the protein content in pigeon pea seed ranges between 18-22\%, while high-quality leaf ranges between 10 $15 \%$ crude protein. Leaf and young pods can be harvested and conserved or fed fresh. Under good grazing management, pigeon pea has lasted up to 5 years. Regeneration of foliage is moderate when the plants are younger but becomes poorer as the plants become woody and near the end of its life (Cook et al., 2005). Studies conducted by ICRISAT (2014) in Australia, Colombia, China, and India reported the production of $30-50 \mathrm{t} / \mathrm{h}$ a yield of pigeon pea.

Fodder scarcity is widespread in many areas of the Philippines. The diversity in morphological traits of pigeon pea makes it a crop with great potential in many parts of the country. It is reported that pigeon pea is grown on 5.2 million hectares of land in Asia, Eastern and Southern Africa, Latin America, and the Caribbean (ICRISAT, 2014). In the Philippines, initial research activities on pigeon pea started in 1975 as a sustainable crop. According to Saxena et al. (2010), it was conducted in collaboration with the National Agricultural Research System (NARS), specifically the Philippine Council for Agriculture, Forestry, and Natural Resources Research and Development (PCARRD) in different state universities, namely, Mariano Marcos State University (MMSU) in Batac, Ilocos Norte; University of the Philippines (UP); and Quirino province. However, research activities were discontinued in 1997.

In 2005, according to Saxena et al. (2010) the project was revived to gather information on the production and utilization of 16 new cultivars of pigeon pea. It was tested in MMSU which ICPL 88039 produced the highest yield of $875 \mathrm{~kg} / \mathrm{ha}$ and after rationing, it generated a yield of $625 \mathrm{~kg} / \mathrm{ha}$ and was discovered as the best alternative crop after rice production. Testing in MMSU also showed ICP 7035 as a potential intercrop for maize. Aside from the aforementioned varieties, other ICRISATbred lines that showed good potential were ICPL 87119, ICPL 87091, and ICPL 20092.

Recognizing the potential of the cultivars in Ilocos Region, forage-type pigeon pea variety were tested in multi-location study trials in different regions of the Philippines. This study aims to identify and evaluate the best forage type pigeon pea variety in Central Luzon. The information generated in the study would serve as guide to those who would like to adopt the forage type pigeon pea variety for ruminant feeding. 


\section{MATERIALS AND METHODS}

\section{Source of Materials}

Four forage-type varieties of pigeon pea (ICPL 87119, ICPL 13092, ICP 7035, and 2009) were used as test varieties for the experiment. Seeds were acquired from the International Crops Research Institute for the Semi-Arid Tropics (ICRISAT).

\section{Experimental Site}

The experiment was conducted at the Small Ruminant Center, Central Luzon State University, Science City of Muñoz, Nueva Ecija. Soil texture at the experimental site was characterized as deep heavy clay having a soil $\mathrm{pH}$ of 5. Soil phosphorous and potassium level was $8 \mathrm{ppm}$ and $157.80 \mathrm{ppm}$, respectively. Central Luzon is under Type 1 climate condition with two distinct seasons, dry season during the month of June to November and wet season during the month of December to May. Annual average rainfall was $133 \mathrm{~mm}$ and temperature ranging from $26.7^{\circ} \mathrm{C}$ to $35.5^{\circ} \mathrm{C}$.

\section{Experimental Design}

The study was laid out in Randomized Complete Block Design with three replications and the pigeon pea forage varieties as treatment. An area of 555 square meters was prepared using complete land preparation. Plot size was $6.75 \mathrm{~m}$ long x $5.5 \mathrm{~m}$ wide having eight rows. Each row had 10 plants spaced at $0.5 \mathrm{~m}$ between plants and $0.75 \mathrm{~m}$ between rows . The distance between plots was 1 meter. A total of 960 plants were planted.

\section{Cultural Practices}

The plants were irrigated twice that was done zero days after planting (DAP) and 12 DAP. The fertilizer rate was $52.5-30-30 \mathrm{~kg} \mathrm{~N}, \mathrm{P} 2 \mathrm{O} 5$, and $\mathrm{K} 2 \mathrm{O}$ per hectare or 10 grams per plant. The amount was applied twice during the experiment. Half of the fertilizer recommendation was applied 12 days after emergence (DAE), while the remaining amount was applied at $30 \mathrm{DAE}$.

\section{Sampling}

For each variety, 30 plants were randomly selected to record data on growth, survival rate, herbage, and dry matter yield. Initial harvest was done 90 DAP and successive harvests were $\quad 60$ days thereafter. Plants were cut two feet from the ground. Harvesting was done early in the morning. Plant height was measured using a meter stick. Experimental plants were sampled and weighed immediately after cutting. The harvested samples were dried for 3-5 days and weighed for dry matter analysis

\section{Statistical Analysis}

Data collected was subjected to analysis of variance (ANOVA) using the General Linear Model (GLM) procedure of Statistica for Windows ${ }^{\text {TM }}$ Released 4.3 (SAS Institute Inc. 1993). 


\section{RESULTS AND DISCUSSION}

\section{Survival Rate at Harvest}

The results of this study in terms of survival was $19 \%$ higher to that observed by Fabunmi et al. (2010) which ranged from 30.3\% to $75.9 \%$ after two consecutive cuttings. The difference between survival rates could be attributed to different cutting height where the study of Fabunmi et al. (2010) was $25 \mathrm{~cm}, 50 \mathrm{~cm}, 75 \mathrm{~cm}$, and $100 \mathrm{~cm}$ above the ground. Occurrence of root and stem contributed to less than $85 \%$ survival rate. The low survival rate of ICPL 20092 (Table 1) was further aggravated by susceptibility to mites. Saxena (2010) suggested that cutting frequency of the cultivars for fodder production would be limited to 2-3 times per year to prevent depletion in nutrient reserves of the plants.

Table 1. Survival rate of plants at harvest, $\%$

\begin{tabular}{lccccc}
\hline \multicolumn{1}{c}{ Variety } & \multicolumn{3}{c}{ Replication } & Total & Mean \\
\cline { 2 - 4 } & I & II & III & & \\
\hline ICPL 87119 & 71.6 & 65.0 & 80.0 & 216.6 & $72.1^{\mathrm{b}}$ \\
ICPL 13092 & 63.3 & 63.3 & 65.0 & 191.6 & $63.8^{\mathrm{b}}$ \\
ICP 7035 & 83.3 & 81.6 & 80.0 & 244.9 & $81.6^{\mathrm{a}}$ \\
ICPL 20092 & 56.6 & 26.6 & 50.0 & 133.2 & $44.3^{\mathrm{c}}$ \\
\hline
\end{tabular}

Means with common letter superscript are not significantly different $(p>0.05)$

\section{Plant Height at First Harvest}

Taller plants are more advantageous for forage production since it generally produces more yields. Pigeon pea can grow from one to four meters high. Plant height of the four varieties at 90 DAP ranged from 92.1 to $199.9 \mathrm{~cm}$. The result was comparable to the study of Bhengra et al. (2010) with $138.3 \mathrm{~cm}$ to $186.9 \mathrm{~cm}$ at 90 DAP under different integrated weed management practices. Pigeon pea varieties ICPL 87119, 13092, and 7035 grew more than $100 \mathrm{~cm}$. Among the varieties, ICP 7035 was taller over the rest (Table 2). The shortest plant was ICPL 20092 which is a long-duration genetic dwarf line variety. Despite this, Saxena et al. (2010) described this variety ideal for contour farming and is a very popular fodder in China and USA.

Table 2. Plant height at first harvest (90 DAP), cm

\begin{tabular}{|c|c|c|c|c|c|}
\hline \multirow[t]{2}{*}{ Variety } & \multicolumn{3}{|c|}{ Replication } & \multirow[t]{2}{*}{ Total } & \multirow[t]{2}{*}{ Mean } \\
\hline & $\mathrm{I}$ & II & III & & \\
\hline ICPL 87119 & 191.9 & 186.7 & 168.6 & 547.2 & $182.4^{\mathrm{b}}$ \\
\hline ICPL 13092 & 163.7 & 177.3 & 154.2 & 495.2 & $165.0^{\mathrm{b}}$ \\
\hline ICP 7035 & 205.9 & 193.8 & 200.1 & 599.8 & $199.9^{a}$ \\
\hline ICPL 20092 & 90.7 & 89.9 & 95.9 & 276.5 & $92.1^{\mathrm{c}}$ \\
\hline
\end{tabular}

Means with common letter superscript are not significantly different $(p>0.05)$

\section{Length of Cutting/re-growth at Different Harvesting Times}

During the first harvest, the three varieties ICPL 87119, 13092, and 7035 had a cutting length of more than $100 \mathrm{~cm}$, which was significantly longer than ICPL 20092 with $31.2 \mathrm{~cm}$ (Table 3). In the second harvest, only ICP 7035 significantly produced re-growth of more than $100 \mathrm{~cm}$ (Table 4). At the third or last harvest, all of the varieties produced re-growth of less than $100 \mathrm{~cm}$. Re-growth ranged from $40.9 \mathrm{~cm}$ to $58.8 \mathrm{~cm}$ during the third harvest. In the study conducted by Fabunmi et al. (2010), the 
length of re-growth of pigeon pea after the initial cutting ranged from 203 to $247 \mathrm{~cm}$. The higher regrowth can be attributed to longer cutting interval of 73 days compared 60 days for this study.

Table 3. Length of cutting at first harvest, $\mathrm{cm}$

\begin{tabular}{|c|c|c|c|c|c|}
\hline \multirow[t]{2}{*}{ Variety } & \multicolumn{3}{|c|}{ Replication } & \multirow[t]{2}{*}{ Total } & \multirow[t]{2}{*}{ Mean } \\
\hline & $\mathrm{I}$ & II & III & & \\
\hline ICPL 87119 & 131.0 & 125.8 & 107.7 & 364.5 & $121.5^{\mathrm{b}}$ \\
\hline ICPL 13092 & 102.8 & 116.4 & 93.3 & 312.5 & $104.6^{\mathrm{b}}$ \\
\hline ICP 7035 & 148.0 & 132.9 & 139.2 & 420.1 & $140.0^{\mathrm{a}}$ \\
\hline ICPL 20092 & 29.8 & 29.0 & 35.0 & 93.8 & $31.2^{\mathrm{c}}$ \\
\hline
\end{tabular}

Means with common letter superscript are not significantly different $(p>0.05)$

Table 4. Length of re-growth at second harvest, $\mathrm{cm}$

\begin{tabular}{|c|c|c|c|c|c|}
\hline \multirow{2}{*}{ Variety } & \multicolumn{3}{|c|}{ Replication } & \multirow{2}{*}{ Total } & \multirow{2}{*}{ Mean } \\
\hline & I & II & III & & \\
\hline ICPL 87119 & 89.1 & 89.4 & 94.7 & 273.2 & $91.0^{\mathrm{b}}$ \\
\hline ICPL 13092 & 86.9 & 94.3 & 92.0 & 273.2 & $91.0^{\mathrm{b}}$ \\
\hline ICP 7035 & 110.7 & 106.1 & 109.5 & 326.3 & $108.7^{\mathrm{a}}$ \\
\hline ICPL 20092 & 47.9 & 43.9 & 49.9 & 141.7 & $47.2^{c}$ \\
\hline
\end{tabular}

Means with common letter superscript are not significantly different $(p>0.05)$

The length of re-growth indicates the ability of the forage to sustain growth and provide biomass for ruminant feeding. The ICP 7035 consistently produced the longest cutting/re-growth of $140 \mathrm{~cm}, 108 \mathrm{~cm}$, and $58 \mathrm{~cm}$ in three consecutive cutting. The difference in re-growth was $22 \%$ lower between the first and second cutting and 58\% lower between the second and third cutting. Likewise, there was a generally declining trend on the length of re-growth for all the varieties (Tables 3, 4, and 5). In a trial by Cook (2005), the frequent cutting of pigeon pea after successive cutting and heavy defoliation was not tolerated by the plant. Pigeon pea has moderate re-growth of foliage when it is young and has poor re-growth as it matures and becomes woody.

Table 5. Length of re-growth at third harvest, $\mathrm{cm}$

\begin{tabular}{|c|c|c|c|c|c|}
\hline \multirow[t]{2}{*}{ Variety } & \multicolumn{3}{|c|}{ Replication } & \multirow[t]{2}{*}{ Total } & \multirow[t]{2}{*}{ Mean } \\
\hline & $\mathrm{I}$ & II & III & & \\
\hline ICPL 87119 & 50.3 & 56.1 & 50.0 & 156.4 & $52.1^{\mathrm{b}}$ \\
\hline ICPL 13092 & 34.9 & 53.6 & 44.3 & 132.8 & $44.2^{\mathrm{b}}$ \\
\hline ICP 7035 & 58.1 & 68.0 & 50.3 & 176.4 & $58.8^{\mathrm{a}}$ \\
\hline ICPL 20092 & 46.9 & 40.5 & 35.5 & 122.9 & $40.9^{\mathrm{b}}$ \\
\hline
\end{tabular}

Means with common letter superscript are not significantly different $(p>0.05)$

\section{Accumulated Herbage Yield per Plant}

ICP 7035 produced the highest herbage yield of 1,232.4 grams per plant which was $14 \%$ higher over ICPL 87119, 41\% that of ICPL 20092, and 44\% compared to ICPL 13092 (Tables 6a, 6b, and 6c). This comparative advantage could be attributed to superior height, bigger stems, and broader leaves. 
Table 6a. Herbage yield per plant at first harvest, $g$

\begin{tabular}{lccccc}
\hline Variety & \multicolumn{3}{c}{ Replication } & Total & Mean \\
\cline { 2 - 4 } & I & II & III & & \\
\hline ICPL 87119 & 609.6 & 530.4 & 392.6 & 1532.6 & $510.8^{\mathrm{a}}$ \\
ICPL 13092 & 287.0 & 356.5 & 225.2 & 868.7 & $289.5^{\mathrm{a}}$ \\
ICP 7035 & 643.6 & 572.6 & 600.7 & 1816.9 & $605.6^{\mathrm{b}}$ \\
ICPL 20092 & 224.5 & 219.4 & 240.8 & 684.7 & $228.2^{\mathrm{a}}$ \\
\hline
\end{tabular}

Means with common letter superscript are not significantly different $(p>0.05)$

Table 6b. Herbage yield per plant at second harvest, $g$

\begin{tabular}{|c|c|c|c|c|c|}
\hline \multirow[t]{2}{*}{ Variety } & \multicolumn{3}{|c|}{ Replication } & \multirow[t]{2}{*}{ Total } & \multirow[t]{2}{*}{ Mean } \\
\hline & $\mathrm{I}$ & II & $\overline{\text { III }}$ & & \\
\hline ICPL 87119 & 429.9 & 448.4 & 508.8 & 1387.1 & $462.3^{a}$ \\
\hline ICPL 13092 & 285.1 & 329.5 & 318.7 & 933.3 & $311.1^{\mathrm{b}}$ \\
\hline ICP 7035 & 509.6 & 477.3 & 506.1 & 1493.0 & $497.6^{\mathrm{a}}$ \\
\hline ICPL 20092 & 347.2 & 332.3 & 396.1 & 1075.6 & $358.5^{\mathrm{b}}$ \\
\hline
\end{tabular}

Means with common letter superscript are not significantly different $(p>0.05)$

Table 6c. Herbage yield per plant at third harvest, $g$

\begin{tabular}{|c|c|c|c|c|c|}
\hline \multirow[t]{2}{*}{ Variety } & \multicolumn{3}{|c|}{ Replication } & \multirow[t]{2}{*}{ Total } & \multirow{2}{*}{ Mean } \\
\hline & I & II & III & & \\
\hline ICPL 87119 & 91.0 & 92.1 & 76.5 & 259.6 & $86.5^{\mathrm{b}}$ \\
\hline ICPL 13092 & 84.5 & 92.4 & 87.9 & 264.8 & $88.2^{\mathrm{b}}$ \\
\hline ICP 7035 & 115.4 & 163.2 & 108.8 & 387.4 & $129.1^{\mathrm{a}}$ \\
\hline ICPL 20092 & 152.0 & 130.0 & 118.5 & 400.5 & $133.5^{\mathrm{a}}$ \\
\hline
\end{tabular}

Means with common letter superscript are not significantly different $(p>0.05)$

It is worth noting that ICPL 20092 had a comparable yield to ICPL 13092 in spite of the 44\% difference in plant height. It was also observed that ICPL 20092 had more dense leaves than ICPL 13092. Therefore, the yield could have been better if it was not infested by mites.

The data presented for the accumulated herbage yield was the sum total of three harvests each variety. At the third harvest, there was a substantial decline in growth performance in all varieties (Table 6c). The re-growth was slow, characterized by smaller leaves and more distinct number of desiccated branches. The results corroborate with the findings of Saxena et al. (2010) wherein the crop allows two to three productive harvests.

Generally, the limitation of pigeon pea to sustain longer period for forage production or the ability to tolerate continuous defoliation is a major consideration as a sustainable feed resource.

\section{Leaf to stem ratio}

Among the varieties, ICPL 20092 exhibited high leaf to stem ratio, while ICPL 87119 and 13092 have the low but nearly identical ratio (Table 7). The morphological characteristic of ICPL 20092 having dense leaves gives it a significantly higher leaf to stem ratio of 3.18:1 ( $p>0.5$ ). 
Table 7. Leaf to stem ratio of forage pigeon pea varieties

\begin{tabular}{ll}
\hline Variety & Leaf to stem ratio \\
\hline ICPL 87119 & $1.73: 1^{\mathrm{a}}$ \\
ICPL 13092 & $1.70: 1^{\mathrm{a}}$ \\
ICP 7035 & $2.0: 1^{\mathrm{b}}$ \\
ICPL 20092 & $3.18: 1^{\mathrm{c}}$ \\
\hline
\end{tabular}

Means with common letter superscript are not significantly different $(p>0.05)$

The higher leaf to stem ratio of ICPL 20092 among the four varieties provides an advantage to both animal and husbandry man. The higher ratio of edible plant parts translates to higher dry matter intake of animals per unit volume of harvested forage. Less time is spent in cleaning unconsumed parts or feed refusals. Consequently, less time is spent in harvesting fodder for ruminants. Re-growth is readily consumed by goats with minimal waste, as ICPL 20092 has thin, short, and succulent stems. Again, if not for the mite infestation during the vegetative period, ICPL 20092 would have gained higher yields.

\section{Projected vs Adjusted Herbage Yield per Hectare}

The projected herbage yield (PHY) per hectare was based on 100 percent plant populations of 26,666 per hectare. However, actual herbage yield (AHY) per hectare was computed based on the survival rate of the four varieties. Mean plant weight (stem+leaves) during the three cutting cycles were used to make projection yields on a per hectare basis.

The projected yield per hectare across pigeon pea varieties ranged from 18.4 to 32.9 tons (Table 8), while the adjusted yield ranged from 2.8 to 8.9 tons per hectare (Table 9). The PHY and AHY had a difference of 15.6-24 t/ ha due to low survival rate. Among the varieties, ICP 7035 significantly $(p<0.5)$ produced the highest yield both on projected $(32.9 \mathrm{t} / \mathrm{ha})$ and adjusted yield $(8.9$ t/ha). ICPL 20092 and 13092 was found comparable but obtained the lowest yield on per hectare basis.

Table 8. Projected herbage yield per hectare, $\mathrm{t} / \mathrm{ha}$

\begin{tabular}{|c|c|c|c|c|c|}
\hline \multirow[b]{2}{*}{ Variety } & \multicolumn{3}{|c|}{ Replication } & \multirow[t]{2}{*}{ Total } & \multirow[t]{2}{*}{ Mean } \\
\hline & $\bar{I}$ & II & III & & \\
\hline ICPL 87119 & 30.1 & 28.5 & 26.0 & 84.7 & $28.2^{\mathrm{b}}$ \\
\hline ICPL 13092 & 17.5 & 20.7 & 16.8 & 55.0 & $18.4^{c}$ \\
\hline ICPL 7035 & 33.8 & 32.3 & 32.4 & 98.5 & $32.9^{\mathrm{a}}$ \\
\hline ICPL 20092 & 19.2 & 18.1 & 20.1 & 57.6 & $19.2^{c}$ \\
\hline
\end{tabular}

Means with common letter superscript are not significantly different $(p>0.05)$

Table 9. Adjusted herbage yield per hectare, $\mathrm{t} / \mathrm{ha}$

\begin{tabular}{|c|c|c|c|c|c|}
\hline \multirow[b]{2}{*}{ Variety } & \multicolumn{3}{|c|}{ Replication } & \multirow[t]{2}{*}{ Total } & \multirow[t]{2}{*}{ Mean } \\
\hline & $\mathrm{I}$ & II & III & & \\
\hline ICPL 87119 & 7.0 & 6.6 & 8.1 & 21.7 & $7.2^{\mathrm{b}}$ \\
\hline ICPL 13092 & 3.6 & 3.6 & 4 & 11.2 & $3.7^{\mathrm{c}}$ \\
\hline ICP 7035 & 9.2 & 8.8 & 8.8 & 26.8 & $8.9^{\mathrm{a}}$ \\
\hline ICPL 20092 & 3.6 & 1.6 & 3.2 & 8.4 & $2.8^{c}$ \\
\hline
\end{tabular}

Means with common letter superscript are not significantly different $(p>0.05)$ 


\section{Projected vs Adjusted Dry matter Yield per Hectare}

Among the varieties, ICP 7035 significantly obtained the highest projected dry matter yield per hectare with an average of 8.1 tons and adjusted projected dry matter of 2.2 tons. A similar result was obtained by Cook et al. (2005) in the adjusted DM yield with $2 \mathrm{t} /$ ha in semi-arid conditions and dry lands of Africa. Meanwhile, ICPL 13092 and 20092 obtained the lowest DM yields with 0.9 and 0.7 tons per hectare, respectively.

Adjusted dry matter production differ across varieties from 2.1 to $6.7 \mathrm{t} / \mathrm{ha}$ during the six month period. These results is comparable to annual DM leaf yields of well-established forage legumes such as G. sepium (5-16 t/ha), L. leucocephala (1-15 t/ha), and F. macrophyla (3-12 t/ha), according to Cook et al. (2005), except in this study the yield was obtained in just under six months.

Table 10. Projected dry matter yield per hectare $(\mathrm{t} / \mathrm{h})$

\begin{tabular}{lccccc}
\hline \multicolumn{1}{c}{ Variety } & \multicolumn{3}{c}{ Replication } & Total & Mean \\
\cline { 2 - 4 } & I & II & III & & \\
\hline ICPL 87119 & 7.6 & 7.2 & 6.5 & 21.3 & $7.1^{\mathrm{b}}$ \\
ICPL 13092 & 4.4 & 5.3 & 4.3 & 14.0 & $4.6^{\mathrm{a}}$ \\
ICPL 7035 & 8.3 & 8.0 & 8.0 & 24.3 & $8.1^{\mathrm{c}}$ \\
ICPL 20092 & 4.8 & 4.5 & 5.1 & 14.4 & $4.8^{\mathrm{a}}$ \\
\hline
\end{tabular}

Means with common letter superscript are not significantly different $(p>0.05)$

Table 11. Adjusted dry matter yield per hectare, $\mathrm{t} / \mathrm{ha}$

\begin{tabular}{|c|c|c|c|c|c|}
\hline \multirow[t]{2}{*}{ Variety } & \multicolumn{3}{|c|}{ Replication } & \multirow[t]{2}{*}{ Total } & \multirow[t]{2}{*}{ Mean } \\
\hline & $\bar{I}$ & II & III & & \\
\hline ICPL 87119 & 1.7 & 1.7 & 2.0 & 5.3 & $1.8^{\mathrm{b}}$ \\
\hline ICPL 13092 & 0.9 & 0.9 & 1.0 & 2.8 & $0.9^{a}$ \\
\hline ICP 7035 & 2.3 & 2.2 & 2.2 & 6.7 & $2.2^{\mathrm{c}}$ \\
\hline ICPL 20092 & 0.9 & 0.4 & 0.8 & 2.1 & $0.7^{\mathrm{a}}$ \\
\hline
\end{tabular}

Means with common letter superscript are not significantly different $(p>0.05)$

\section{Plant diseases}

Stem and root rot affected all four varieties with an infection rate that ranged from 10.55 to 14.5 percent. This is equivalent to $25-34$ plants affected by the disease across the varieties. Wilt is very common in pigeon pea and has been observed to occur in wet and dry conditions. Analysis of variance revealed no significant differences among varieties (Table 10). To avoid disease spread, uprooting of infected plants at an early stage of development was done. Infected plants were destroyed by burning.

Table 12. Incidence of stem and root rot infection, $\%$

\begin{tabular}{|c|c|c|c|c|c|}
\hline \multirow[t]{2}{*}{ Variety } & \multicolumn{3}{|c|}{ Replication } & \multirow[t]{2}{*}{ Total } & \multirow[t]{2}{*}{ Mean } \\
\hline & $\mathrm{I}$ & II & III & & \\
\hline ICPL 87119 & 6.6 & 11.6 & 13.3 & 31.5 & $10.5^{\mathrm{ns}}$ \\
\hline ICPL 13092 & 15.0 & 11.6 & 16.6 & 43.2 & $14.4^{\mathrm{ns}}$ \\
\hline ICP 7035 & 10.0 & 6.6 & 16.6 & 33.2 & $11.0^{\mathrm{ns}}$ \\
\hline ICPL 20092 & 13.3 & 18.3 & 11.6 & 43.2 & $14.4^{\mathrm{ns}}$ \\
\hline
\end{tabular}

Means with common letter superscript are not significantly different $(p>0.05)$ 


\section{Insect attack and damage}

Among the varieties, ICPL 20092 was prone to mite attack (Figure 1), while the rest were found resistant. Pigeon pea mite is a vector of pigeon pea sterility mosaic virus. It causes mosaic and mottling symptoms on pigeon pea leaves and inhibit flower induction. The mite infestation on ICPL 20092 significantly affected plant vigor, thus, resulting to lower DM yield.

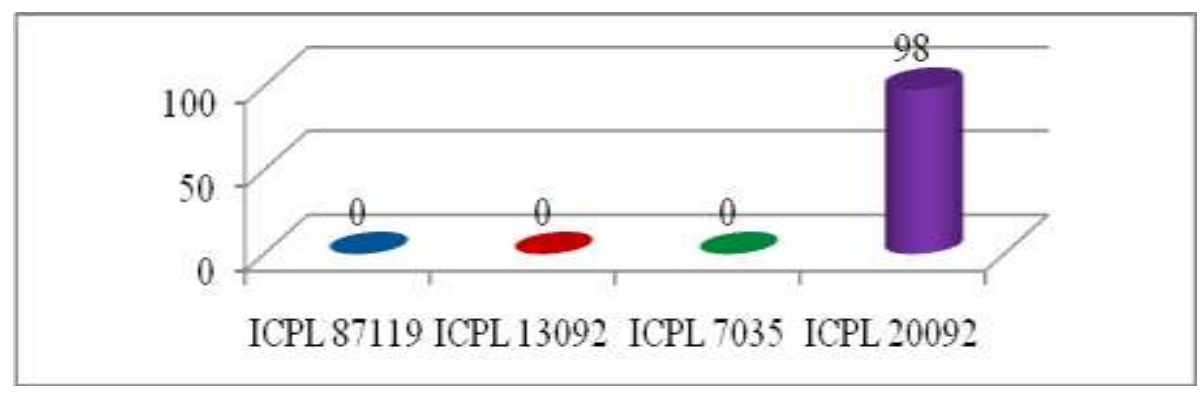

Figure 1 . Susceptibility to mite infestation, $\%$

Pest management using chemical control is not recommended. The withdrawal time of commonly used pesticides exceed the growing period for forages, therefore, leaving behind traces of chemicals when it is harvested and eventually utilized as ruminant feed. Residues of chemical insecticides have deleterious effects on growth and survival of ruminants. Several options to control the occurrence of mite infestation (Saxena, 2006) are destruction of mite infested plants by burning, crop rotations to reduce vector population, and regular monitoring of the crop through integrated pest management.

\section{SUMMARY AND CONCLUSION}

The agronomic performance of pigeon pea to produce biomass for ruminant feeding was assessed. The recommended pigeon pea variety is ICP 7035, which produced excellent yields and had a good crop stand. Although pigeon pea has comparable DM yields to other shrub/tree legumes, it lacked the ability to tolerate continued defoliation. Costs in re-establishment after three harvests should be considered to assess economic gains for feeding to small ruminants.

\section{Acknowledgements}

The study had been undertaken with funding support from the Philippine Council for Agriculture, Aquatic, and Natural Resources Research and Development. 


\section{REFERENCES}

Bhengra S, Jeral ME, Kandeyang S and Pandey AC. 2010. Comparative Study of Growth and Yield Attributing Characters of Pigeon Pea (Cajanus cajan) under Integrated Weed Management Practices. International Journal of Tropical Agriculture. ISSN 0254-8755, 255-260.

Cook, B.G., Pengelly, B.C., Brown, S.D., Donnelly, J.L., Eagles, D.A., Franco, M.A., Hanson, J., Mullen, B.F., Partridge, I.J., Peters, M. and Schultze-Kraft, R. 2005. Tropical Forages: an interactive selection tool., [CD-ROM], CSIRO, DPI\&F(Qld), CIAT and ILRI, Brisbane, Australia.

Fabunmi TO, Adigbo SO, Odedina JN. 2010. Effect of Survivability of Pruning on Growth, Yield and Survivability of Pigeon pea (Cajanus cajan) in Pigeon pea / Pepper Alley Cropping. Journal of Agricultural Science and Environment. ISSN 1595-9694, 18-26.

ICRISAT. 2014. International Crops Research Institute for the Semi-arid Tropics. www.icrisat.org/ (accessed April 2014).

Rao SC, Phillips WA, Mayeux HS and Phatak SC 2003. Forage and Grazing lands. Potential Grain and Forage Production of Early Maturing Pigeon pea in the Southern Great Plains. Crop Science Society of America 43:2212-2217.

SAS Institute Inc. (1993). SAS/STATSoft: Syntax, Version 6, first Edition. SAS Institute Inc., Cary, NC.

Saxena KB, MG, Mula MG, Sugui FP, Layaoen HL, Domoguen RL, Pascua ME, Mula RP, Dar WD, Gowda CLL, Kumar RV and Eusebio JE. 2010. Pigeon pea: A Resilient Crop for the Philippines Dry lands. Information Bulletin No.85.Patancheru 502 324, Andhra Pradesh, India: International Crops Research Institute for the Semi-Arid Tropics. 80 pp. ISBN: 978-92-9066-529-8 Order code: IBE 085A.

Saxena KB. 2006. Seed Production Systems in Pigeon pea. Patancheru 502 324, Andhra Pradesh, India: International Crops research institute for the Semi-Arid Tropics. 76 pp. ISBN: 92-9066-4908. Order code BOE 040B.

Sharma S, N. Agarwal, and P. Verma. 2011. Pigeon pea (Cajanus cajan L .): A hidden treasure of regime nutrition. J. Funct. Environ. Bot. 1:91-101. doi:10.5958/j.2231-1742.1.2 .010

Van Soest PJ. 1994. Nutritional ecology of ruminant. $2^{\text {nd }}$ edition. Ithaca, New York, USA: Cornell University Press. 